\title{
FDI in Retailing: Lead to Economic Growth and Better Value to End Consumers
}

\author{
V. Selvam ${ }^{1} \&$ Desti Kannaiah ${ }^{2}$ \\ ${ }^{1}$ Professor of Commerce, SSL, VIT University, Tamil Nadu, India \\ ${ }^{2}$ Senior Lecturer, School of Business, James Cook University, Singapore \\ Correspondence: V. Selvam, Professor of Commerce, SSL, VIT University, Vellore, Tamil Nadu, India. E-mail: \\ Kannaiah.desti@jcu.edu.au or destiram2000@yahoo.com
}

Received: July 1, 2015

doi:10.5539/ijef.v7n10p1

\begin{abstract}
Retailing is the largest private industry in India and second largest employee after agriculture. It has emerged as one of the most appealing investment areas for domestic as well as foreign investors. And this high growth curve owes some credit to a booming economy and liberalized Foreign Direct Investments (FDI). The sector contributes to around 10\% of GDP. With over 12 million retail outlets, India has the highest retail outlets density in the world. This sector witnessed significant development in the past 10 years from small unorganized family owned retail formats to organized retailing liberalization of the economy, rise in the per capital income and growing consumerism has encouraged large business and venture capitalist in investing in retail infrastructure. The key factors that drive growth in retail industry are young demographic profile, increasing consumer aspirations, growing middle class incomes and improving demand from rural markets. Also, rising incomes and improvements in infrastructure are enlarging consumer markets and accelerating the convergence of consumer tastes. India is one of the biggest economics in the world in terms of purchasing power. The market size of Indian retail industry is about US \$312 billion FDI has boomed in post-reform India. Moreover, the composition and type of FDI has changed considerably since India has opened up to world markets. This has fuelled high expectations that FDI may serve as a channel to the higher economic growth of India. Foreign investors are extremely eager on charisma in Indian retail sector. Incontrovertibly, FDI in retail is budding as a sort of litmus trial to the government's pledge to liberalization. In this background, this paper try to give a better view of what is the retailing, role of FDI in retail industry, retail trade at global level, Current Scenario and Changing Indian Consumer. This paper also tries to analyse the FDI in retailing: lead to economic growth and better value to end consumers.
\end{abstract}

Keywords: foreign direct investment, retailing, economic growth, better value, Indian consumers

\section{Introduction}

Retail sector has undergone significant changes and is fast emerging. Inviting foreign investments to enter into retail trade in India is a progressive measure. India is currently the ninth largest retail market in the world. This sector witnessed transformation of unorganized family owned formats to organized retailing. The retail revolution will restructure the Indian economy and would be beneficial to the consumers, customers, small and medium-scale business and farmers. The emergence of organized retailing will help accelerate productivity growth, improve competitiveness, provide better job opportunities, offer more product variety and develop the agriculture and processed food industries. India is likely to surpass world's best retail economics by 2042 because of factors like good talent pool, unlimited business opportunities due to huge markets and availability of quality raw materials. Industry players at the Technopak's 8th Marketing and Retail Conclave felt that GDP growth coupled with rising income levels is leading to increase the purchasing power of the middle class. This would change the outlook of retail business in the country (Lata Kothari, 2007). Based on the above, this paper studies the FDI in retailing lead to economic growth and better value to end consumers in India.

\section{Operational Definition}

\subsection{Retailing}

The interface between the producer and the individual consumer buying for personal consumption. This excludes direct interface between the manufacturer and institutional buyers such as the government and other bulk 
customers. Retailing is the last link that connects the individual consumer with the manufacturing the distribution chain.

\subsection{Organized Retail}

There are owned by private or government and are based on some principles and procedures like Wal-Mart, Big Bazaar, and Possess license to sell the product.

\subsection{Foreign Direct Investment (FDI)}

FDI refers to an investment in a foreign country, where the investor retains control over the investment (Sodersten, 1979). It also defines as a transfer of package of resources across the countries and that includes capital, technology, management and marketing expertise (Odozo, 1995). FDI is the investment in a foreign country through the acquisition of a local company or the establishment there of an operation on a new (Greenfield) site. To put in simple words, FDI refers to capital inflows from abroad that is invested in or to enhance the production capacity of the economy. According to the International Monetary Fund (IMF), FDI refers to an investment made to acquire lasting or long-term interest in enterprises operating outside of the economy of the investor (Viney, 2013). As defined by UNCTAD (2008), FDI is an investment involving a long-term relationship and reflecting a lasting interest and control by a resident entity in one economy in an enterprise resident in an economy other than that of the FDI. It is commonly argued that foreign firms bring capital and technology to least developed countries (LDCs) which these countries desperately need to foster growth.

\section{A Foreign Affair Sector Wise FDI Equity Inflows}

The pro FDI lobby says that inflow of foreign money will boost economy by making a sector more competitive. Those who oppose it state that FDI might ruin local industries and take away the profits to a foreign land which had otherwise stayed within the country. An analysis of FDI inflows since April 2000 shows that services sector, real estate, telecommunication, computer and software industries, food processing industries, electrical equipment and consultancy services have witnessed the highest FDI in past 14 years. The following table 1 depicts the percentage of total FDI inflows in India including service sector from April 2000 to August 2014.

Table 1. Percentage of total FDI inflows in India

\begin{tabular}{lcc}
\hline Sector & \$ million & \% of total inflows (sectors with more than 1\% FDI are taken \\
\hline Services sector & 40,546 & 17.66 \\
Construction (real estate) & 23,752 & 10.35 \\
Telecommunication & 16,499 & 7.19 \\
Computer software and hardware & 13,191 & 5.75 \\
Food processing industries & 6,036 & 2.63 \\
Electrical equipment's & 3,717 & 1.62 \\
Consultancy services & 2,677 & 1.17 \\
\hline
\end{tabular}

Source: DIPP, Times of India, $25^{\text {th }}$ November, 2014.

\section{FDI in Retail: A Win-Win Situation}

Consumers need change, suppliers and farmers need change and the infrastructure needs change. It is the win-win situation for all. The government has made sure that only serious people with money come into the sector. If through this move, $\$ 10-\$ 20$ billion of investments come in (Kishore Biyani, 2011). According to Confederation of India Industry (CII) and Boston Consulting Group (BCG) the organized retail would help consumers save 5-10\% in specific categories. This would lead to an aggregate $\$ 25-\$ 30$ billion, equal to $0.5 \%$ of GDP (CII-BCG report, 2011). Institutionalising the retail chain will bring the cash economy into accounted economy. There will be greater use of credit cards and accountability (Butani, 2011). The important issue of economic prosperity is always linked to massive inflows of FDI into a nation. It provides impetus for accelerating economic development for a country (Yusop \& Keong, 2002).

\section{Retail Trade at Global Level}

The data pertaining to retail trade in India and at South East Asia level was depicted in the following table 2. It is very clear from the table that India's organized retail is less than 4 per cent and unorganized retail is 96 per cent compared to other countries situated in South East Asia. 
Table 2. Retail trade in India and South East Asia

\begin{tabular}{lcc}
\hline Country & Organized Sector & Unorganized Sector \\
\hline Malaysia & 50 & 50 \\
Thailand & 40 & 60 \\
Philippians & 35 & 65 \\
Indonesia & 25 & 75 \\
China & 20 & 80 \\
South Korea & 15 & 85 \\
\hline
\end{tabular}

Source: CRISIL.

\section{FDI in Retailing: Current Scenario}

The current scenario of organised retail in the country was $\$ 20$ billion in the year 2010. In the year 2011, it was reported that while the overall retail market was valued at $\$ 4,450$ billion, organized retail was about $6 \%$ of the value. Analysis further observe that by 2015 , value of the overall retail industry will reach $\$ 720$ billion with the share of organized retail expected to reach $9 \%$ to $10 \%$. It is reported that till date FDI in single brand retail has been received to the tune of $\$ 45$ million. If we take a closer look at share of various product categories in the retail market, we find that clothing as a category leads followed by durables and foods and beverages. It is further believed that the true potential of the Indian retail industry can be reached by going for enhanced FDI in the retail sector (Kishology Roy, 2013). The following table 3 shows the share of retail market in India.

Table 3. Share of retail market in India

\begin{tabular}{lcc}
\hline Retail market & Share of organized retailing & Percentage \\
\hline Clothing and accessories & 10.1 & 36 \\
Durables and electronics & 3.8 & 14 \\
Food and beverages & 3.5 & 12 \\
Foot wear & 2.6 & 9 \\
Food wear & 2.2 & 8 \\
Leisure & 1.8 & 6 \\
Furniture & 1.7 & 6 \\
Accessories, jewellery and watches & 1.5 & 5 \\
Pharmacy & 0.7 & 2 \\
Health and personal care & 0.2 & 1 \\
Total & 28.1 & 100 \\
\hline
\end{tabular}

Source: kishology Roy, The Economic Challenger, 2013.

\section{FDI: Changing Indian Consumer}

The face of Indian retailing has to change given the socio-economic-cultural changes that are taking place. The customer's preferences, tastes, life-style and attitude towards shopping are undergoing a lot of changes (Ganesan, 2007). FDI in retailing really enables domestic customers will benefit getting great variety and quality products at all price points. Due to economics of operations, production facilities will be available at a cheaper rate. Retailing is one of the world's largest private industry. The changing paradigm in FDI in retail industry superimposes its cost factors. Opening more organized retail industry to FDI will provide benefits in terms of advance employment, organized retail stores, availability of quality products at a better and cheaper price, new job opportunities in retail and real estate, growth in economy, better price and large brand range to choose from, new infrastructure development and better price for farmers in vegetable and fruit retail.

In the retailing business, the intermediaries dominate between the manufacturers or producers and the consumers. Hence, the farmers and manufactures lose their actual share of profit margin. This issue can be resolved by FDI, as farmers might get contract farming where they will supply to a retailer based upon demand and will get good cash for that, they need not to search for buyers. For consumers, they will get variety of products at low prices compared to market rates, and will have more choice to get international brands at one place (Sasikala, 2011).

\section{Review of Literature}

To justify the need of present study, the following literature has been reviewed. FDI has emerged as the most 
important source of external financial resource for developing countries and has become a significant part of economy in the developing (Kumar, 2001). Markets are more open are likely to create significant economic welfare gains through more efficient allocation of resources (Kumar, 2002). FDI is expected to contribute to economic growth which is believed to improve living standards of the local population (Sharma and Badara, 2010). An advantage would be the ones with better locations, superior customer service and the offers on prices and product range, in turn calling for negotiations skills with suppliers. Still foreign entrants making quick inroads into market share may not be all that easy. Under current conditions in permitting FDI, only 53 cities (those with population of over one million) are open to foreign presence (Bhavana Acharya, 2011). The farmers will benefit from FDI as they will be able to get better prices for their produce. The elimination of the intermediate channels in the procurement process will lead to reduction of prices for consumers. By allowing FDI in the Indian market, it will teach the local retailers about real competition and help in ensuring that they give better service to Indian consumers (Jayadev, 2012).

The entry of the global retail giant like Wal-Mart, Tesco, etc. will certainly provide a large variety of products to the Indian customers. Commodities from all over the world can be collected from one store, which will help customers to save time and energy. International brands that were not available due to non-accessibility by domestic retailers could easily be made available through these global payers (Sunil Kumar, 2012). The recent debate on the acceptability of foreign direct investment in the retail sector in India has been mostly political. It is necessary to look into the pros and cons of FDI in retail from a purely economic point of view (Abhirup Sarkar, 2013). FDI has helped India to attain a financial stability and economic growth with the help of investments in different sectors. FDI has boosted the economic life of India and on the other hand there are critics who have blamed the government for ousting the domestic inflows. After liberalization of trade policies in India, there has been a positive GDP growth rate in Indian economy (Viney, 2013). FDI in retail is boon to consumers and farmers (Venkatesan, 2013). The entry of the retain giants like Walmart will benefit the consumers by addressing the problem of inflation through price reductions and reduction in agricultural waste (Ankush Bhargava, 2014). Yet supermarket shares in India are currently very low (around 2\%), due to the country's massive and complex small retail sector. Supermarkets there face the 20/20/20 challenge: they must grow their food sales by $20 \%$ a year for 20 years just to reach a $20 \%$ market share. Such unprecedented growth would still leave more traditional channels holding $80 \%$ of the food (Periyasamy, 2014). Easy availability of Debit/Credit cards has contributed significantly to a strong and growing online consumer culture in India. With the online medium of retail gaining more and more acceptance, there is tremendous growth opportunity for retail companies, both domestic and international (Atul Pandey, 2014). The above literature shows the important contribution on FDI in retailing: Lead to economic growth and gives better value to end consumers. It is also evident from the above literature that majority of the consumers get more opportunities from FDI in retailing in India. In light of above literature, the present study attempts to identify the problems on consumers towards FDI in retailing in south India.

\subsection{Statement of Problem}

FDI inflow to developing countries is mainly vertical in nature because their markets are not matured i.e., they do not have well established institutions. The vertical FDI takes place when a firm relocates only a part of its production process but not the whole production (Mariotti et at., 2003). FDI in multi-brand retail will certainly affect the survival of the unorganized sector. Unorganized retailers who have already been facing tough competition from the domestic organized retailers will have to face retailers like Tesco, Walmart, etc. Small traders, shop owners and farmer organizations find the proposal shocking and say it would endanger the livelihood of four core people directly engaged in retailing food and non-food items, and twenty crore people depends on then (Sify Finance, 2010). Global retailers owing their outsourcing skills, resources and facilities from the government, will be able to crush competition and charge monopolistic prices (Khandelwal, 2010). The Indian farmers earn only $30 \%$ of the consumer price. In some developed countries, this varies between 50 and $70 \%$. Losses in the fruits and vegetable supply chains rise because of multiple intermediaries, handling points, poor technology and supply chain mismanagement. For every rupee a consumer spends on tomatoes, only 54 paise go to farmers and for value addition. The rest is divided between profit margins of intermediaries and leakages along the supply (CII-BCG Report, 2011). The logic that multinational retailers will not invade the turf of the local kirana is also misplaced since significant consumers spend takes place in the neighbourhood stores. Over time, the multinational retailer will want to capture this by setting up neighbourhood stores and not be confined to suburban hypermarkets (Dilip James, 2011). The literature and statement of problems cited above does not discuss the larger economics of scale to help lower consumer price, better lifestyle, more variety and easier availability of more products, helps customer to save time and energy, buy best brands and provide better value to end customers in India in the sense that no attempt is made to extract the important underlying factors of 
large economic growth and better value to end consumers and their relationship with demographic variables. Majority of the studies prove contradictory results of economic growth, better value and more opportunities to end consumers towards FDI in retailing in India. The present work takes care of these research gap.

\subsection{Research Question}

In this study the researchers are seeking to answer the following question.

Is FDI in retailing really helps to improve the Indian economy, gives better value and more opportunities to end consumers in India?

\subsection{Research Hypothesis}

In order to conduct this study and to answer the proposed question and considering the results achieved by the previous studies, the following null hypotheses are formulated:

Ho: (Null hypotheses) There is no significant relationship between education and FDI in retailing leads to economic growth, gives better value and more opportunities to end consumers in India.

\subsection{Objectives of the Study}

The following objectives were framed to know the FDI in retailing helps to improve economy, gives better value and more opportunities to end consumers in India.

1) To understand the effect of demographic profile of the respondents in relation with FDI in retailing.

2) To identify the FDI in retail sector will lead to rapid economic growth in India.

3) To ascertain the effect of education affecting the FDI in retailing gives better value and more opportunities to end consumers in India.

\section{Methodology of the Study}

The research attempt is empirical in nature. The present study is based on primary as well as secondary data. The sources of primary data were collected through a well framed and structured questionnaire. The secondary data were collected from published sources like journals, magazines, internet, newspapers, and books, annual reports of FDI in retailing and earlier studies. The sample for this study consisted of respondents from five states from South India namely Chittor city from Andhra State, Bangalore city from Karnataka State, Kollam city from Kerala State, Pondicherry city form Pondicherry State and Vellore city from Tamil Nadu State. Convenience sampling was used to collect the samples. A total of 625 samples were issued and only 586 samples were collected out of which only 542 samples were taken for analysis and remaining 44 samples were not taken into account due to incompleteness of the questionnaire. Before conducting field survey, the questionnaire was pre-tested and a few modifications were made. A final version of structured questionnaire with two sections was developed to find out viz., 1. Demographic profile and 2. FDI in retailing leads to economic growth, gives more value and opportunities to end consumers' in India. The questionnaire of the study consisted of multiple choices and Likert's five point scale from 1-Strongly Disagree to 5-Strongly Agree. The SPSS package 20 was used for analysis. Statistical tools like percentage analysis, frequency distribution and one way ANOVA were applied.

\subsection{Test of Reliability}

The current study has used Cronbach's alpha, which is the most widely used measure for testing the reliability. It requires only a single test administration and is easy to compute when using a correlation matrix. Cronbach's alpha is expressed as $\alpha=\mathrm{Np} /[1+\mathrm{p}(\mathrm{N}-1)]$ (Carmines \& Zeller, 1979), where $\mathrm{N}$ is the number of statements and $\mathrm{p}$ is the mean inter-item correlation. The dataset used for the study had a Cronbach's alpha of 0.792. As per Hair et al. (1998), the generally agreed upon lower limit is 0.70 , while (Carmines \& Zeller, 1979) believe that the alpha should not be below 0.80 for widely used scales. Considering these guidelines, it would be appropriate to conclude that the data used for one way ANOVA exhibit a very good reliability.

\subsection{Limitations of the Study}

The major limitation of this study is that the findings may not be universally acceptable as it is research paper. The perceptions of the same respondents may differ at different points of time. In case, if more number of sample respondents had been collected for the study, the results might have differed. Another limitation of this study is that the researcher does not consider the opinion of the foreign direct investors, producers and retailers, who are the major stakeholders in single or multi brand retailing. The study area is restricted only in South India and it does not cover the whole India. The study period is limited to six months only i.e., from 1st January, 2014 to 31st May, 2014. 


\section{Analysis and Findings}

\subsection{Percentage Analysis}

The data pertaining to demographic profile of the respondents were given in Table 4 .

Table 4. Demographic profile

\begin{tabular}{cccc}
\hline Variable & Category & Frequency & Percentage \\
\hline Gender & Male & 289 & 53 \\
& Female & 253 & 47 \\
& Total & $\mathbf{5 4 2}$ & $\mathbf{1 0 0}$ \\
\hline Nativity & Rural & 233 & 43 \\
& Urban & 309 & 57 \\
& Total & $\mathbf{5 4 2}$ & $\mathbf{1 0 0}$ \\
\hline Education & B.Com & 105 & 19 \\
& BBA & 39 & 07 \\
& B.Sc & 42 & 08 \\
& BCA & 56 & 10 \\
& M.Com & 92 & 17 \\
& MBA & 93 & 12 \\
& MS (SE) & 67 & 09 \\
& MCA & 48 & $\mathbf{1 0 0}$
\end{tabular}

Source: Primary data.

\subsection{Inference}

From table 3 it is inferred that, majority (53\%) of the respondents belong to male category and $47 \%$ respondents belong to female category. With regard to native, 309 out of 542 respondents belong to urban area and 233 respondents out of 542 belong to rural area. Educational qualification is the base for any decision making and it is also very interesting to hear from this study that 105 (maximum) respondents were educated B.Com and 93 respondents were educated MBA. Therefore, it is very clear to say that all the respondents having either arts or science degree.

\subsection{One Way ANOVA-Testing of Hypotheses}

The data pertaining to education and FDI in retailing leads to economic growth, gives better value and more opportunities to end consumers in India were given in Table 5.

Table 5. One way ANOVA

\begin{tabular}{|c|c|c|c|c|c|}
\hline Variable & Df & Mean square & $\mathbf{F}$ & Sig. & Hypothesis \\
\hline & 9 & 167.692 & 1432.13 & $.000^{*}$ & Accepted \\
\hline \multirow[t]{2}{*}{ FDI in retailing leads to rapid economic growth in India } & 532 & .076 & & & \\
\hline & 541 & & & & \\
\hline FDI in retailing gives more value to end consumers in & 9 & 167.170 & 1570.20 & $.014^{*}$ & Accepted \\
\hline \multirow[t]{2}{*}{ India } & 532 & .136 & & & \\
\hline & 541 & & & & \\
\hline \multirow[t]{3}{*}{ Better life style helps to increase the standards of living } & 9 & 143.025 & 1303.08 & $.001^{*}$ & Accepted \\
\hline & 532 & .107 & & & \\
\hline & 541 & & & & \\
\hline \multirow[t]{3}{*}{ Larger economics of scale to help lower consumer price } & 9 & 150.171 & 1283.01 & $.022 *$ & Accepted \\
\hline & 532 & .142 & & & \\
\hline & 541 & & & & \\
\hline \multirow[t]{3}{*}{ More variety and easier availability of more products } & 9 & 77.967 & 714.634 & $.000^{*}$ & Accepted \\
\hline & 532 & .132 & & & \\
\hline & 541 & & & & \\
\hline
\end{tabular}




\begin{tabular}{|c|c|c|c|c|c|}
\hline \multirow[t]{3}{*}{ Increased purchasing power parity of the consumers } & 9 & 162.322 & 1268.58 & $.072 *$ & Not \\
\hline & 532 & .126 & & & Accepted \\
\hline & 541 & & & & \\
\hline \multirow[t]{3}{*}{ Helps customers to save time and energy } & 9 & 116.410 & 1247.62 & $.020^{*}$ & Accepted \\
\hline & 532 & .143 & & & \\
\hline & 541 & & & & \\
\hline \multirow[t]{3}{*}{ Get a wide assortment of quality goods } & 9 & 96.652 & 956.732 & $.007 *$ & Accepted \\
\hline & 432 & .168 & & & \\
\hline & 541 & & & & \\
\hline \multirow[t]{3}{*}{ Ability to buy best brands across various categories } & 9 & 189.793 & 1406.36 & $.063^{*}$ & Not \\
\hline & 532 & .176 & & & Accepted \\
\hline & 541 & & & & \\
\hline
\end{tabular}

Source: Primary data; * Significance at $5 \%$ level.

\section{Findings}

From the above table 6, it is inferred that, the calculated value of one way ANOVA for six variables which is less than the hypothetical value $(\alpha=0.05)$ at $5 \%$ level of significance namely FDI in retailing leads to rapid economic growth in India as shown $F=1432.13$, Probability $(\mathrm{P})$ value $=0.000<0.05$ and FDI in retailing gives more value to end consumers in India as shown $F=1570.20(\mathrm{P})$ value $=0.014<0.05$. The other opportunity variables like better life style helps to increase the standards of living as shown $\mathrm{F}=1303.08(\mathrm{P})$ value $=0.001<$ 0.05 , larger economics of scale to help lower consumer price as shown $\mathrm{F}=1283.01(\mathrm{P})$ value $=0.022<0.05$, more variety and easier availability of more products as shown $\mathrm{F}=714.634(\mathrm{P})$ value $=0.000<0.05$, helps customers to save time and energy as shown $\mathrm{F}=1247.62(\mathrm{P})$ value $=0.020<0.05$ and get a wide assortment of quality goods as shown $\mathrm{F}=956.732(\mathrm{P})$ value $=0.007<0.05$. Therefore, the null hypothesis is not accepted. Hence, there is some statistical significant relationship between education and FDI in retailing leads to rapid economic growth, gives better value and more opportunities to end consumers in India.

It is also very important to note that, the calculated value of one way ANOVA for two opportunity variables which is more than the hypothetical value $(\alpha=0.05)$ at $5 \%$ level of significance namely increased purchasing power parity of the consumers as shown $\mathrm{F}=1268.58(\mathrm{P})$ value $0.072>0.05$ and ability to buy best brands across various categories as shown $\mathrm{F}=1406.36(\mathrm{P})$ value $0.063>0.05$. Therefore, the null hypothesis is accepted. Hence, there is no statistical significant relationship between education and FDI in retailing leads to economic growth, gives better value and more opportunities to end consumers in India.

\section{Conclusion}

The present study was conducted with the purpose of understanding the changes takes place in the minds of the consumers regarding FDI in retailing. This paper makes an analysis of FDI in retailing, Current Scenario, buying behaviour, Changing Indian Consumer towards economic growth, gives better value and more opportunities to end consumers in India. To summarize, FDI in retail sector's impact changed the lifestyle of the Indian consumers drastically. The evident increase in consumerist activity is colossal which has already chipped out a money making recess for the Indian organized retail sector. With the onset of a globalized economy in India, the Indian consumer's psyche has been changed. People have become aware of the value of money. Nowadays the Indian consumers are well versed with the concepts about quality of products and services. These demands are the visible impacts on consumers towards FDI in the Indian organized retail sector. Government liberalization of Indian trade and economy allowing foreign participation in retail sector has registered substantial growth in the retail sector. This is because of consumer in the young generation, urbanization, growth of personal disposable income, development of infrastructure etc. Considering the nascent state of this sector, India has a very strong investment potential for foreign players. Hence, from the above research study it is evident that FDI in retail will certainly help to lead Indian economy, increase more value and opportunities to end consumers. Therefore, FDI in retailing is need of the hour to all consumers for better life style, lower consumer price, more variety and reasonable price, save time and energy and to get quality of goods in India.

\section{Suggestion}

FDI in Indian Retail not only prove fruitful for the economy as a whole but it will also integrate this sector with the global retail market. The results of FDI in China are a case for example here. In Chinese market development of $100 \%$ FDI was done in 2004, today its retail sector is the second largest in value in the world. In a true 
potential scenario, opening up of FDI can increase organized retail market size to $\$ 260$ billion by 2020 . Therefore, FDI in retail is not only necessary for economic growth and thereby providing better value and more opportunities to end consumers in India. Further, protection of all stakeholders in retail sector may be done by regulatory policy of government and right implementation of the same. The upcoming changes in FDI in retailing should consider the economic interest of all the stakes holders from supplier to consumer and then this would be a welfare growth of Indian retail sector.

\section{References}

Abhirup, S. (2013). Understanding FDI in Retail: What Can Economic Principles Teach Us? Economic and Political Weekly, XLVIII(1), 12-16. http://strategicstudyindia.blogspot.in/2013/01/understanding-fdi-in-retail.html

Ankush, B., \& Rajanikant, V. (2014). Foreign Direct Investment and Retailing-A New Way Forward. Asian Journal Management, 5(2), 117-120. Retrieved from http://www.ipublishing.co.in/ajmrvol5no2.html

Atul, P., Sachin, B., \& Sanjay, M. (2014). An Empirical Study of Organized Retailers and Their Impact on Consumer's Buying Behaviour. Asian Journal of Management, 5(2), 121-124. Retrieved from http://www.ipublishing.co.in/ajmrvol5no2.html.

Bhavana, A. (2011). What's in Store for Retail. The Hindu, Business Line, Sunday, December 4, p. 11. Retrieved from http://www.thehindubusinessline.com

Butani. (2011). War for the Mart. Sunday. The Times of India, December 4, p. 9. Retrieved from http://www.timesofindia.indiatimes.com

Carmines, E., \& Zeller, R. (1979). Reliability and Validity Assessment. Beverly Hills: Sage University Paper, Sage Publication. http://dx.doi.org/10.4135/9781412985642

CII-BCG. (Report 2011). War for the Mart. Sunday, The Times of India, December 4, p. 9. Retrieved from http://www.timesofindia.indiatimes.com.

Dilip, J. (2011). No Retail Therapy in Sight. Business Standard, Weekend 3/4, December 2, p. 14. Retrieved from http://www.business-standard.com

DIPP. (2014). A Foreign Affair: Sector Wise FDI Equity Inflows. The Time of India, Tuesday, November 25, p. 12. Retrieved from http://www.timesofindia.indiatimes.com

Gansean. (2007). FDI Retail Trade in India. The Economic Challenger, 35(9), 40-45. Retrieved from http://economicchallenger.net

Hair, J., Anderson, R., Tatham, R., \& Black, W. (1998). Multivariate Data Analysis. New Jersey: Prentice-Hall International Edition.

Jayadev, B. J., \& Sijusebastian. (2012). Influence of FDI on Retail Sector. Yojana, 21-26. Retrieved from http://yojana.gov.in/archives.asp

Kandelwal, P. (2010). Is FDI in Retail is Good Idea. Business Standard, New Delhi. Retrieved from http://www.business-standard.com

Kisholoy, R. (2013). FDI in Retail: Dissecting the Reality. The Economic Challenger, 58(15), 2-5. Retrieved from http://economicchallenger.net

Kishore, B. (2011). War for the Mart. Sunday, The Times of India, December 4, p. 9. Retrieved from http://www.timesofindia.indiatimes.com

Kumar. (2001). Infrastructure Availability, FDI Inflows and their Export Orientation: A Cross Country Exploration. Research and Information System for Development Countries, No. 1. 2. Retrieved from http://www.ris.org.in.

Kumar. (2002). Globalization and the Quality of Foreign Direct Investment. Oxford: Oxford University press. Retrieved from http://www.nageshkumar.org

Lata, K. (2007). India Retail: A Big Story. The Economic Challenger, 35(9), 3-6. Retrieved from http://economicchallenger.net

Mariotti, S. M., Mutinelli, \& Piscitello, L. (2003). Home Country Employment and Foreign Direct Investment: Evidence from the Italian Case. Cambridge Journal of Economics, 27, 419-431. http://dx.doi.org/10.1093/cje/27.3.419 
Odozi, V. A. (1995). An Overview of Foreign Investment in Nigeria: 1960-1995. Occasional paper, CBN Research Development, Nigeria. Retrieved from http://www.academia.edu/4300371

Periyasamy. (2014). Role of FDI in Retail Industry. International Journal of Management, IT and Engineering, 4(11), 115-123.

Sasikala. (2011). FDI in Retail Sector. HRD Times, 14(11), 13-14.

Sharma, K., \& Bandara, Y. (2010). Trends, Patterns and Determinants of Australian Foreign Direct Investment. Journal of Economic Issues, 44(3), 661-676. http://dx.doi.org/10.2753/JEI0021-3624440305

Sify Finance. (2010). Battle Ahead for Government in Allowing Foreign Retailers. Retrieved from http://www.sify.com

Sodersten, B. O. (1979). International Economics. Macmillan Press.

UNCTAD. (2008). World Investment Report 2008, Mongolia: Country fact sheet. New York and Geneva: U United Nations Publication. Retrieved from http://www.a-acc.org

Venkatesan. (2013). FDI in Retail is Boon to Consumers and Farmers. The Hindu, Thursday 2, p. 1. Retrieved from http://www.nrisa.org

Viney, \& Kalpana, H. (2013). FDI Inflow in India: A Cursory Look. The Economic Challenger, 60(15), 39-44.

Yusop, Z., \& Keong, C. C. (2002). Foreign Direct Investment in the Malaysian Manufacturing Sector. In Azali et al. (Eds.), APEBC Proceedings (Vol. 1, pp. 356-364). Universiti Putra, Malaysia, Serdang.

\section{Copyrights}

Copyright for this article is retained by the author(s), with first publication rights granted to the journal.

This is an open-access article distributed under the terms and conditions of the Creative Commons Attribution license (http://creativecommons.org/licenses/by/3.0/). 